\title{
Discharge characteristics of weirs of finite-crest width
}

\author{
BY \\ N.S. GOVINDA RAO, \\ AND \\ D. MURATIDHAR, \\ PROFESSOR OF GIVIL AND HYDRAULIC ENGINEERING \\ RESEARCF SCHOLAR, GIVIL AND HYDRATIC ENGINEERING SECTION \\ INDIAN INSTITUTE OF SCIENCE, BANGaLORE 12, INDIA
}

\begin{abstract}
This paper presents a comprehensive analysis for the discharge chartcteristics of weirs of finile crest width. Based on a considerable amount of experimental work, these weirs have been classified as long-crested weirs, broad-crested weirs, narrow-crested weirs and sharp-crested weirs and discharge equations have been developed for each range.
\end{abstract}

\section{INTRODUCTION}

The experiments by Thomas E. Blackwell (1850) [1] on weirs with broad crests were made on the side pond of Kennet and Avon Canal, England. The weir had an adjustable crest in the vertical plane. Both flat and sloping crests with vertical upstream and downstream faces were used. The discharge was measured volumetrically. The experiments showed larger coefficient for weirs with sloping crest. The phenomenon of nappe springing clear-off the crest for higher ratios of head to width of crest was noticed and recorded.

\section{Experiments of Fteley and Stearns [1,2].}

The experiments by Fteley and Stearns [1, 2], 1877 , on weirs with $2,3,4,6$ and 10 inch wide respectively were done in the Sudbury River conduit, Boston. A formula was developed for the discharge in terms of corrections to be applied to heads acting on the broad-crested weir to give head on an equivalent thin-edge weir.

Theoretical approaches for the determination of discharge on broad-crested weir were put forth by Belanger [5] (1849), Flament [5] (1900), Mullins [1] (1890), Unwin and Frizell [1] (1899). These formulae were later confirmed by experiments.

Experiments of Bazin [1, 3*, 4].

The classical experiments by Henry Bazin [1] (1886), on flow of water over broad-crested weirs

\footnotetext{
* Original not referred.
} 
of various shapes were tried in a concrete flume $700 \mathrm{ft}$. long, $6.56 \mathrm{ft}$. wide. Tests included weirs of $1.148,1.64,2.46 \mathrm{ft}$. height, with crests horizontal or sloping, upstream and downstream faces vertical or sloping, with corner at entrance to the weir crest square or rounded. Few observations were by volumetric measurements of discharge and the rest were by using a calibrated weir. The experiments clearly revealed facts about the modification of nappe forms, its effect on the discharge coefficient and elucidate the whole problem of flow of water over weirs.

\section{Experiments of the United States Board of Engineers on deep waterways $[1,4]$.}

Experiments were made by George W. Rafter and Gardener S. Williams (1899) at Cornell University Hydraulic Laboratory on weirs $4.5 \mathrm{ft}$. high and $6.56 \mathrm{ft}$. wide situated in a channel of $48 \mathrm{ft}$. in length. The tests included weirs with crest horizontal or sloping, upstream and downtream faces vertical or sloping. The discharge was measured by a calibrated weir.

\section{Experiments of the United States Geological Survey [1].}

These experiments were made by Robert $\mathrm{E}$. Horton and Gardener S. Williams, 1903, at Cornell University Hydraulic Laboratory. Tests included weirs of height $11.25 \mathrm{ft}$. and crest width which varied from 0.479 to $16.302 \mathrm{ft}$. They had crests horizontal or sloping with upstream and downstream faces vertical. The discharge was measured by a calibrated weir. The experiments showed agreement regarding the behaviour of nappe put forth by Bazin, Fteley and Stearns.

\section{Experiments of Woodburn [6].}

These experiments were made by James $G$. Wodburn, 1932, at the University of Michigan, in a rectangular wooden flume. The experiments included weirs $1.75 \mathrm{ft}$, high with crests, width of which varied from 10 to $15.5 \mathrm{ft}$. horizontal or in slopes or in combination of slopes from 0 to 0.085 and the crest corner at the entrance to the weir crest rounded or sharp. The discharge was measured by a $90^{\circ} \mathrm{V}$-Notch. The experiments showed that the broad-crested weir could function in the modular range even for high submergence ratios. Almost all the head could be recovered by provision of suitable crest slope to form a hydraulic jump and that the location of critical depth was not the same for all discharges.

\section{Experiments of Doeringsfeld and Barker [7].}

Assuming parallel flow over the weir at a depth equal to half the head at the upstream end of the weir, and also hydrostatic pressure distribution, Doeringsfeld and Barker (1941) developed a theoretical formula for discharge over the broad-crested weir as a function of ratio of the head acting on the weir to the height of the weir. Experiments were conducted at Minnesota on weirs $2.25 \mathrm{ft}$. wide, of heights varying from 0.313 to $1.424 \mathrm{ft}$. in a glass flume $40 \mathrm{ft}$. long. $1.68 \mathrm{ft}$. wide and at Washington on weirs 1.12 and $1.65 \mathrm{ft}$. wide, and of heights 0.262 and $0.471 \mathrm{ft}$. respectively to substantiate the theoretical approach. The discharge was measured by a sharp-crested weir.

John Hackney, in his discussion, pointed out that for conditions assumed by the authors, the data of Bazin, Cornell tests as reported by Horton, and Woodburn do not agree with the above theoretical approach.

Elwood Morris used a weir of horizontal crest width $8.42 \mathrm{ft}$. with vertical faces for his experiments and established the depth of parallel flow across the weir as 0.4 times the head acting upon.

H. J. Tracy [9], 1957, analysed the existing literature on broad-crested weirs to clearly interpret the effect of various parameters, pertaining to the characteristics of flow, fluid properties and weir geometry, on the discharge coefficient. He pointed out that broad-crested weirs could be classified as short, normal and long based on the width of weir crest and that for long weirs the observations of brink depth agreed fairly with the prediction of Hunter Rouse (1936) for a free over fall.

The available information on the weirs of finite crest width provide controversial results. This is because of the variation of conditions under which the investigations have been carried out by the different workers.

A comparison of results of previous investigators is given in Figure 1. In these results the coefficient of discharge is computed from the equation

where:

$$
\mathrm{Q}=\mathrm{C}_{1} \mathrm{LH}_{0}^{3 / 2}
$$

$Q$ is the discharge across the weir;

$C_{1}$ is the coefficient of discharge; 


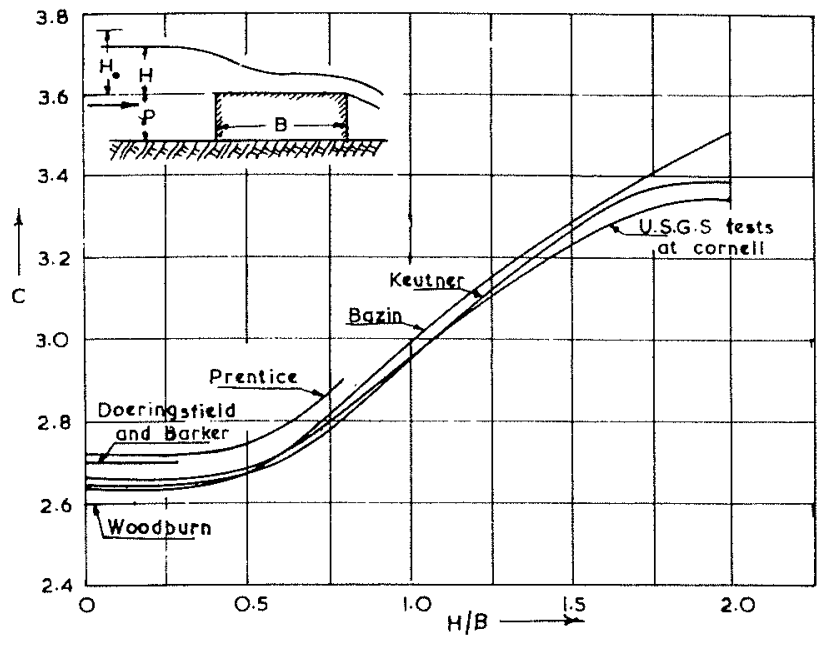

Fia. 1. - Comparison of previous investigation (taken from Ref. 5).

$I$ is the length of the weir, equal to the width of approach channel, and

$\mathrm{H}_{0}$ is the effective head on the crest equal to $\mathrm{H}+\mathrm{V}^{2} / 2 g$, where $\mathrm{H}$ is the actual head on the crest and $\mathrm{V}$ is the mean velocity of approach in the channel.

The main difficulty with this equation is that the discharge computation can be made only through a process of successive approximation. To overcome this fundamental difficulty, in recent times, all weir equations are written in the modified form :

$$
\mathrm{Q}=\mathrm{CLH}^{3 / 2}
$$

In this equation the effect of velocity of appro-

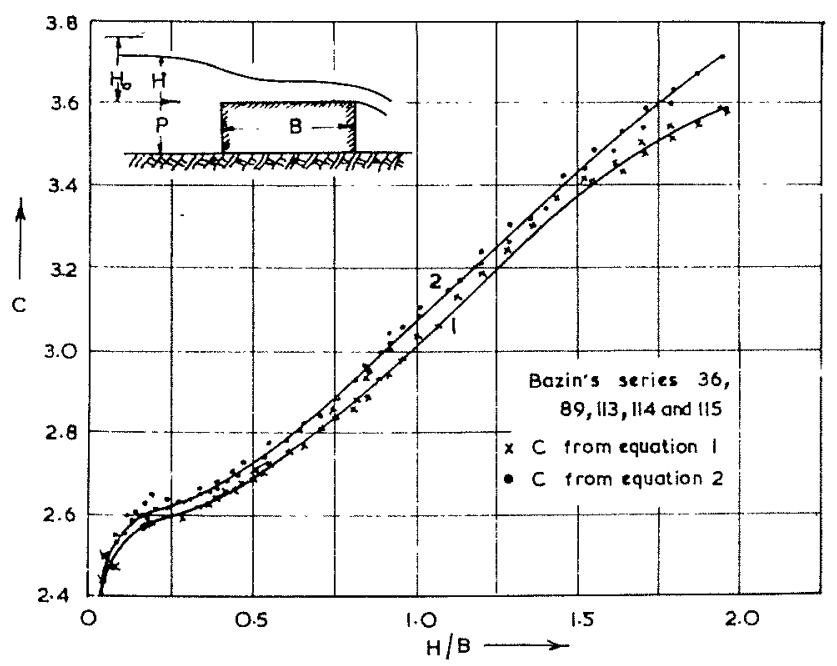

FIG. 2. - Comparison of $\mathrm{C}$ from equations 1 and 2. (Data taken from Ref, 1). ach is coupled with the other factors into one common coefficient of discharge, C. A comparison of coefficients calculated on the basis of above two equations is given in Figure 2. Figure 1 demonstrates the wide disagreement between the various investigations.

\section{EXPERIMENTAL SET.UP AND EXPERIMENTS}

The experimental set-up is shown in Figure 3. Water from a constant head tank enters the experimental flume $2 \mathrm{ft}$. wide, $3 \mathrm{ft}$. high and $51 \mathrm{ft}$. long. The flume is constructed of masonry, smoothly plastered over. Sufficient stilling arrangements in the constant head tank and in the flume occupying a length of about $8 \mathrm{fl}$., were made to simulate uniform-flow at the weir. The downstream edge of the experimental weir was kept at a constant distance of $4 \mathrm{ft}$. from the downstream and of the flume. The approach length provided from the last stilling rack to the upstream edge of the weir varied from a maximum of $35 \mathrm{ft}$. for the 4 inches weir to a minimum of nearly $25 \mathrm{ft}$, for the $10 \mathrm{ft}$. weir.

The experimental weirs constructed with masonry and plastered over, had smooth and plane horizontal crests, vertical upstream and downstream end faces. The upstream face, formed a sharp, right-angled corner at its intersection with the plane of the crest $[10]$. The accuracy in the construction was realised by using wooden templates cut to the exact dimensions of weir and the final dimensions were further verified in each of the series of experiments by the pointgauge and scale capable of reading to $1 / 32$ of an inch. The under side of nappe was acrated by providing suitable openings in the side walls just downstream of the weirs and below the crest, so as not to interfere with the llowing water.

The head over crest was measured by a precision pointgauge, capable of reading to an accuracy of $1 / 144$ th of an inch, located at a distance of 3.5 times the maximum head from the upstream face of weir to avoid the region of surface drawdown. In the early experiments, the discharge was measured volumetrically by measuring tank and a stop watch reading to $1 / 10$ th of a second, the minimum time of collection being 25 sec. and in the latter experiments by a $90^{\circ} \mathrm{V}$-Notch calibrated in position. The measurement of discharge by notch agreed well with volumetric measurements, the maximum deviation being $2 \%$.

Some observations were made of the brinkdepth, the depth of the backed-up water under 


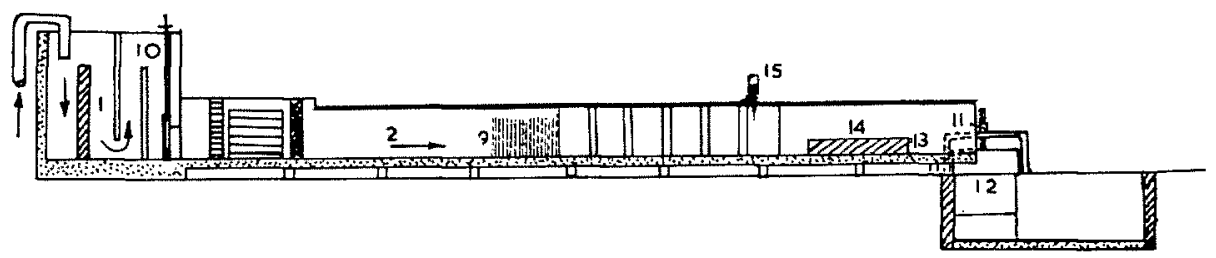

FiG. 3

LONGITUDINAL SECTION

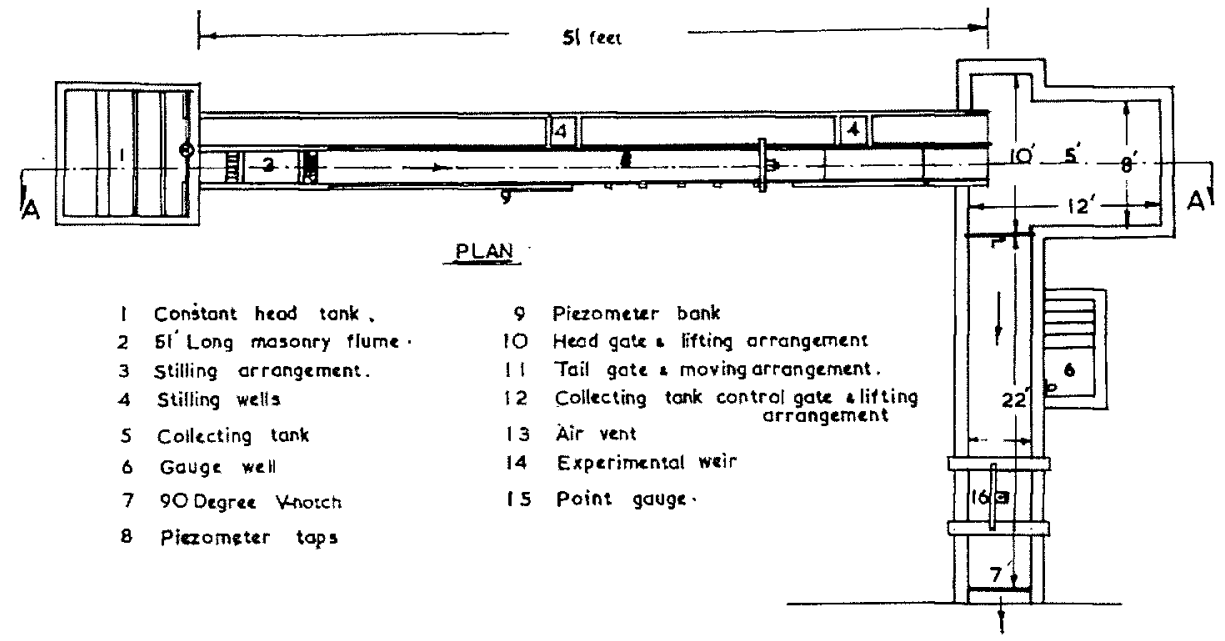

the nappe and depth of the super-critical stream downstream of the weirs. Observations of the flow profiles were made for certain cases.

In all ten series of experiments were conducted as shown in Table I. In the first series the width of the crest, width of the weir parallel to the direction of flow, was kept at 4 inches. The discharge was varied from a minimum value giving a head of about $0.1 \mathrm{ft}$. above the crest to a maximum of about $5 \mathrm{cfs}$. About sixteen experiments were done in each series. The width of the crest was increased in steps to $0.5,0.75,1,2,3,4,5,7$ and $10 \mathrm{ft}$. In all, about 160 tests were done. For all the experiments, the coefficient of discharge was computed using equation (2) and the scope of tests is given in Table I.

TABLE I. - Scope of Tests

\begin{tabular}{|c|c|c|c|c|c|}
\hline $\begin{array}{l}\text { Series } \\
1\end{array}$ & $\begin{array}{c}\text { HeIGHT } \\
\text { OF THE WEIR } \\
\mathrm{P} \\
\text { in } \mathrm{ft} . \\
2\end{array}$ & $\begin{array}{l}\text { WIDTH } \\
\text { OF THE WEIR } \\
\mathrm{B} \\
\text { in } \mathrm{ft} . \\
\mathbf{3}\end{array}$ & $\begin{array}{c}\text { Ratio } \mathrm{H} / \mathrm{P} \\
4 \\
4\end{array}$ & $\begin{array}{c}\text { Ratio } \mathrm{H} / \mathrm{B} \\
5\end{array}$ & $\begin{array}{c}\text { No. OF TESTS } \\
6\end{array}$ \\
\hline $\begin{array}{r}1 \\
2 \\
3 \\
4 \\
5 \\
6 \\
7 \\
8 \\
9 \\
10\end{array}$ & $\begin{array}{l}1.002 \\
1.005 \\
1.009 \\
0.992 \\
1.006 \\
1.012 \\
1.017 \\
1.007 \\
1.007 \\
0.995\end{array}$ & $\begin{array}{c}0.333 \\
0.500 \\
0.750 \\
1.00 \\
2.00 \\
3.00 \\
4.00 \\
5.00 \\
7.00 \\
10.00\end{array}$ & $\begin{array}{l}0.103-0.631 \\
0.108-0.712 \\
0.112-0.734 \\
0.103-0.756 \\
0.109-0.819 \\
0.154-0.802 \\
0.167-0.84 .8 \\
0.138-0.903 \\
0.120-0.881 \\
0.171-0.804\end{array}$ & $\begin{array}{c}0.311-1.896 \\
0.215-1.431 \\
0.151-0.988 \\
0.103-0.756 \\
0.055-0.412 \\
0.052-0.270 \\
0.043-0.216 \\
0.028-0.182 \\
0.024-0.127 \\
0.017-0.080\end{array}$ & $\begin{array}{l}12 \\
12 \\
15 \\
10 \\
26 \\
16 \\
17 \\
17 \\
17 \\
18\end{array}$ \\
\hline
\end{tabular}




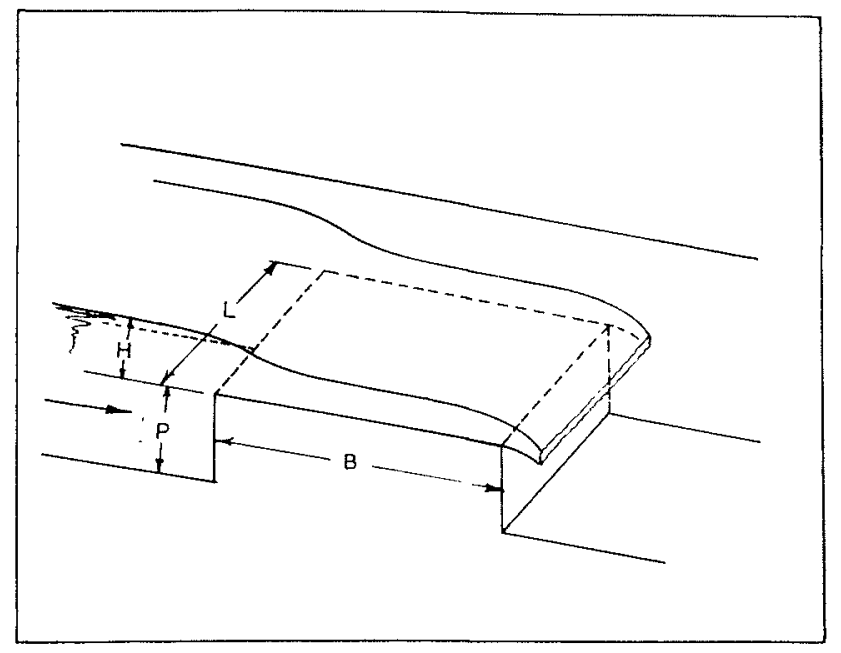

Fir. 4. - Flow over weirs of finite crest width. - Definition sketch

\section{ANALYSIS OF THE RESULTS}

Figure 4 is a schematic representation of flow over weirs of finite crest width. $\mathrm{L}$ is the length of the weir, which is also equal to the which of the channel in which it is located. $P$ is the height of the weir and $B$ is the width of crest (in the direction of flow) and $\mathrm{H}$ is the head over the crest.

Flow over such a weir is a function of the geometrical properties of the weir, characteristics of the flow and the fluid properties. That is:

$$
\mathrm{Q}=f[\mathrm{P}, \mathrm{B}, \mathrm{L}, \mathrm{H}, \gamma, g, \mu, \sigma]
$$

where $\gamma$ is the specific weight of the fluid (here water);

$g$ is the acceleration due to gravity;

$\mu$ is the coefficient of dynamic viscosity of the fluid;

$\sigma$ is the coefficient of surface tension of the fluid.

Using Buckingham's $\pi$ - Theorem it can be shown that

$$
\mathrm{C}=f_{1}[\mathrm{H} / \mathrm{B}, \mathrm{H} / \mathrm{P}, \mathrm{H} / \mathrm{L}, \mathrm{R}, \mathrm{W}]
$$

It can be shown that only when the channel is narrow, i.e., the length of the weir is very much less than the head over the crest, the parameter $\mathrm{H} / \mathrm{L}$ comes into the picture from the considerations of boundary layer growth on the sides. Further this parameter was found to be insignificant in the practical ranges investigated $[9,10]$ and hence not considered.

The effects of viscosity and surface tension being significant only for the smaller heads, the Reynolds number and Weber number were not considered [10]. Hence, the equation was written as:

$$
\mathrm{C}=f_{2}[\mathrm{H} / \mathrm{B}, \mathrm{H} / \mathrm{P}]
$$

On the basis of equation (5), the experimental results are plotted with $C$ on the $Y$-axis and $\mathrm{H} / \mathrm{B}$ on the $\mathrm{X}$-axis with $\mathrm{H} / \mathrm{P}$ as the third parameter as shown in Figure 5 . In all the ten series of experiments, $\mathrm{H} / \mathrm{P}$ varies from about 0.1 to 1.0. But from Figure 5, it is seen that there is no scatter due to the variation in $\mathrm{H} / \mathrm{P}$ i.e., points with different values of $H / P$ follow the same trend. This shows that the coefficient $C$ is a function only of $H / B$, atleast for values of $H / P$ upto unity. But Doeringsfeld and Barker [7] have claimed that for the conditions of parallel flown across the weir i.e., $\mathbf{H} / \mathbf{B} \leqslant 0.4$, $C$ is a function of only $H / P$. To check the validity of this, $C$ is plotted against $H / P$ for the range

$$
0.1 \leqslant H / B \leqslant 0.4
$$

in Figure 6. It is found that the correlation is very bad. The same has been pointed out by John Hackney [7].

On a close observation of Figure 5 , it is seen that the variation of $C$ with $H / B$ does not a single trend. For values of $\mathrm{H} / \mathrm{B}$ upto about 0.10 , it is as shown by curve $\mathrm{I}$, for $\mathrm{H} / \mathrm{B}$ upto about 0.4 it follows a linear trend, which steepened for higher values, at the end of which it passes into the sharp-crested range.

From the observation of the flow pattern, it was observed that a series of standing waves were formed on the crest for values of $H / B$ upto 0.10. Incidentally this is the range in which the coefficient varialion follows the curvilinear trend as shown by Region 1, Figure 5. This range of $0<\mathrm{H} / \mathrm{B} \leqslant 0.1$ is termed as the Long Weir. The variation of the coefficient with $H / B$ is found to be:

$$
\mathrm{C}=3(\mathrm{H} / \mathrm{B})^{0.022}
$$

from the double-log plot in Figure 7 .

For $H / B$ ranging from 0.1 to about 0.35 , region 2 , $\mathrm{C}$ varies linearly with $\mathrm{H} / \mathrm{B}$ as given by the equation:

$$
\mathrm{C}=0.15(\mathrm{H} / \mathrm{B})+2.82
$$

For $H / B$ ranging from 0.45 to 1.5 to 1.9 , region 3 , (depending upon the particular value of $\mathrm{H} / \mathrm{T}$ as 


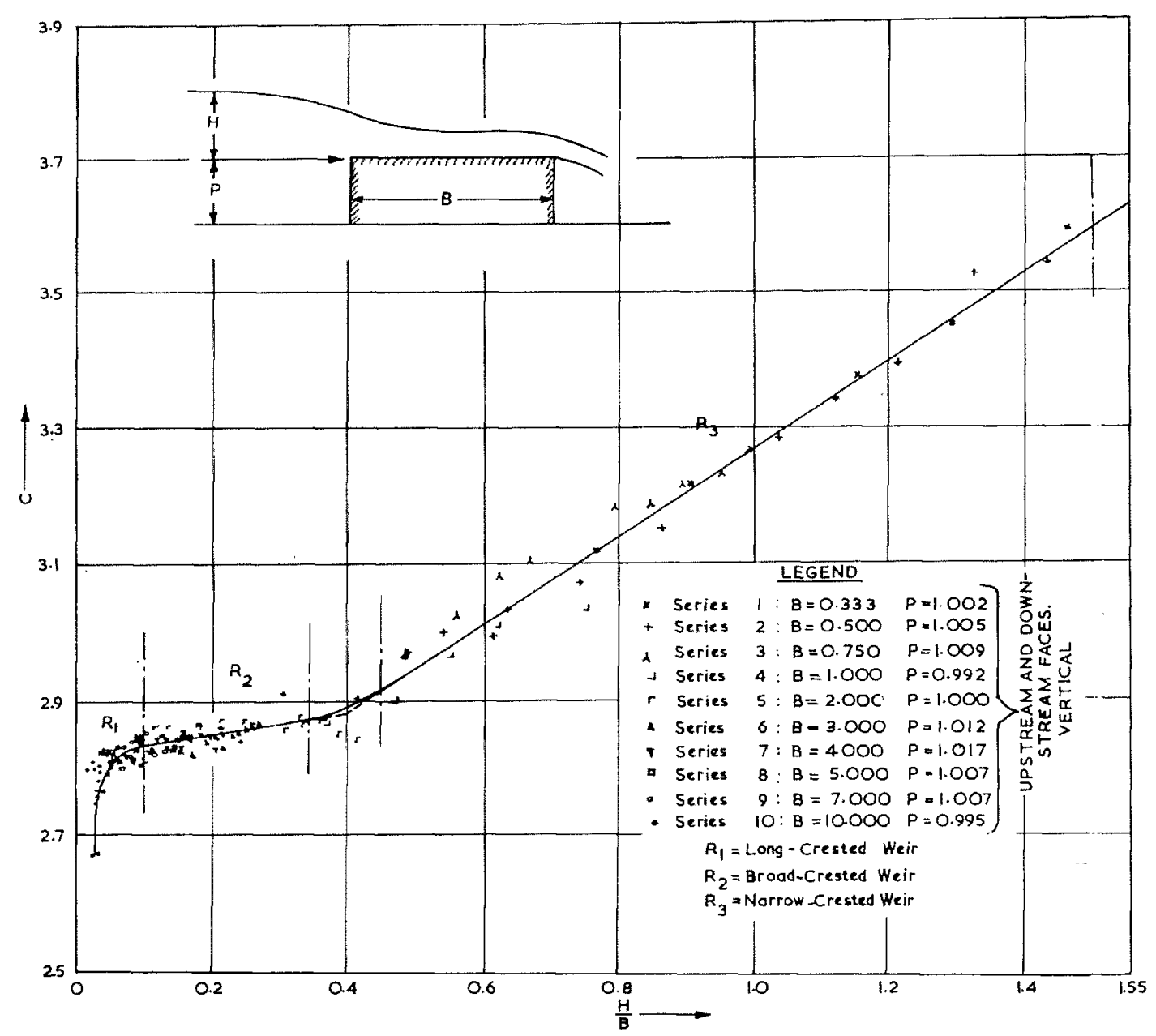

FII. 5

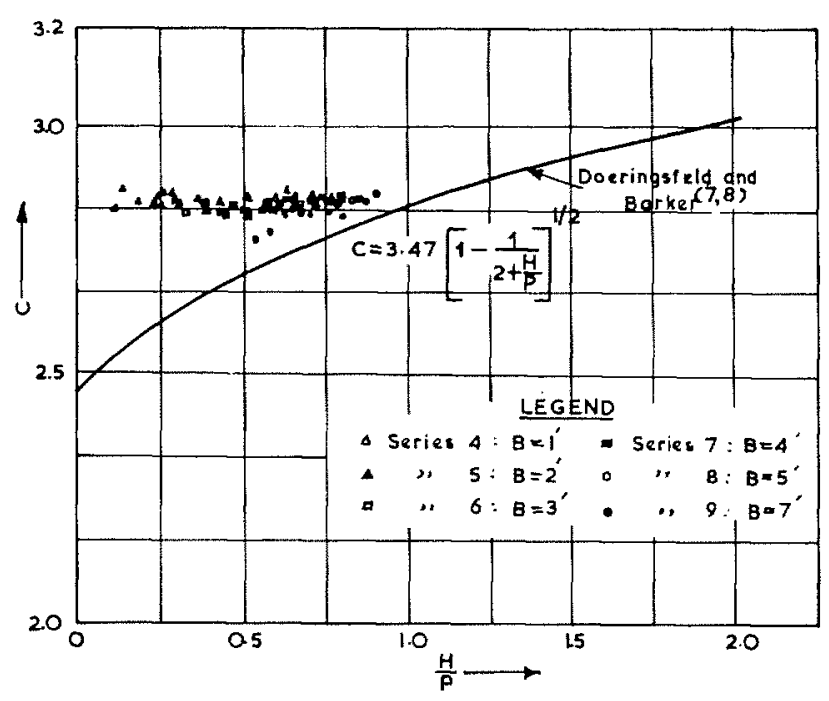

FIG. 6

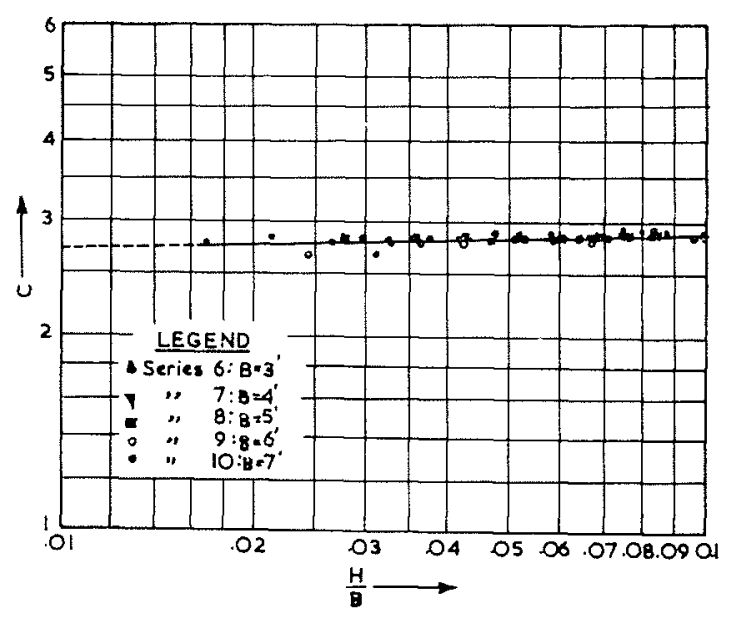

Frg. 7 


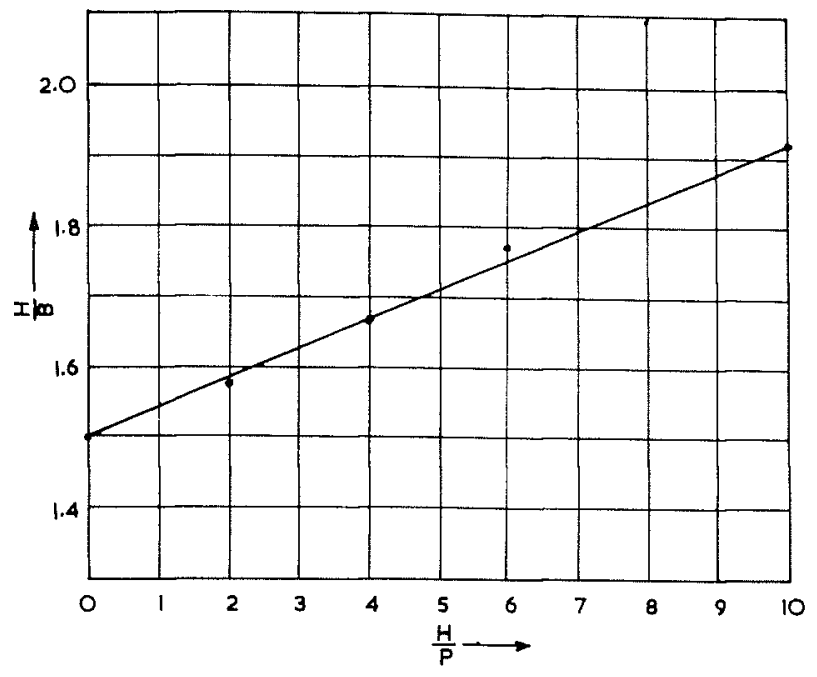

FtG. 8. - Limit of narrow-crested wear.

(Data taken from Ref. 10).

will be shown later), $C$ varies with $H / B$ as given by the equation:

$$
\mathrm{C}=0.64(\mathrm{H} / \mathrm{B})+2.63
$$

with a transition in the range $0.35<\mathrm{H} / \mathrm{B}<0.45$. If the straight lines II and III are extended they meet at 0.4 and the intercept between these lines and the transition curve is negligibly small and hence for the sake of simplicity the coefficient variation is taken to follow equation 7 upto a value of $\mathrm{H} / \mathrm{B}$ equal to 0.4 and equation 8 from 0.4 .

Based on these, in the range $0.1 \leqslant H / B \leqslant 0.4$, the weir is said to be broad-crested and narrowcrested in the range $0.4 \leqslant \mathrm{H} / \mathrm{B} \leqslant 1.5$ to 1.9 (depending on particular $H / P$ ). From the observations of flow profiles it is found that in the region 2 the flow across the weir is parallel to the crest for certain portion and is totally curvilinear in the region 3 .

From the observation of the flow pattern, it was found that for higher values of $\mathrm{H} / \mathrm{B}$, the lower nappe springs clear off the crest, touching the weir only at the upstream crest cornerthus functioning as a sharp-crested weir. The approximate values of $H / B$ at which a weir of finite crest width becomes a sharp-crested weir are found out using the profile observations made by Kandaswamy and Rouse [11] for the terminal sharp-crested weirs. It is seen from Figure 8 that the values of $H / B$, at which this change takes place varies with $\mathrm{H} / \mathrm{P}$ and the variation is from 1.5 to 1.9 , following the linear relation :

$$
\mathrm{H} / \mathrm{B}=0.041 \mathrm{H} / \mathrm{P}+1.51
$$

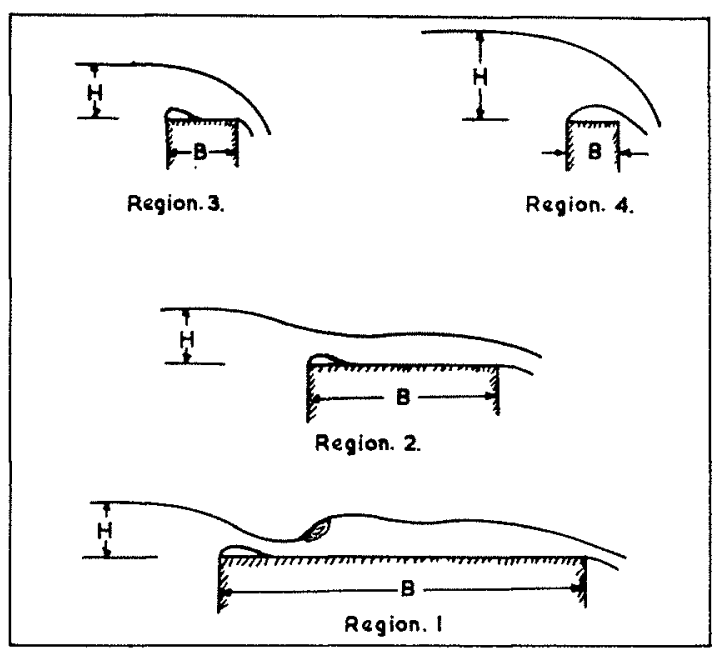

Fia. 9

Flow patterns on weirs of finite-crest width.

The coefficient of discharge for such sharpcrested weirs is the function of $\mathrm{H} / \mathrm{P}$ and the variation of the coefficient is linear as given by Standard Rehbock formula [11].

These different flow patterns are shown in Figure 9.

A comparison between the above results and Bazin's experiments is shown in Figure 10. Even though the trend is the same, Bazin's vaJues are consistently lower. This might be due to the different experimental conditions obtaining in the two investigations. Based on the studies discussed above, the recommended curve for the discharge coefficient of weirs with finite crest width is given in Figure 11.

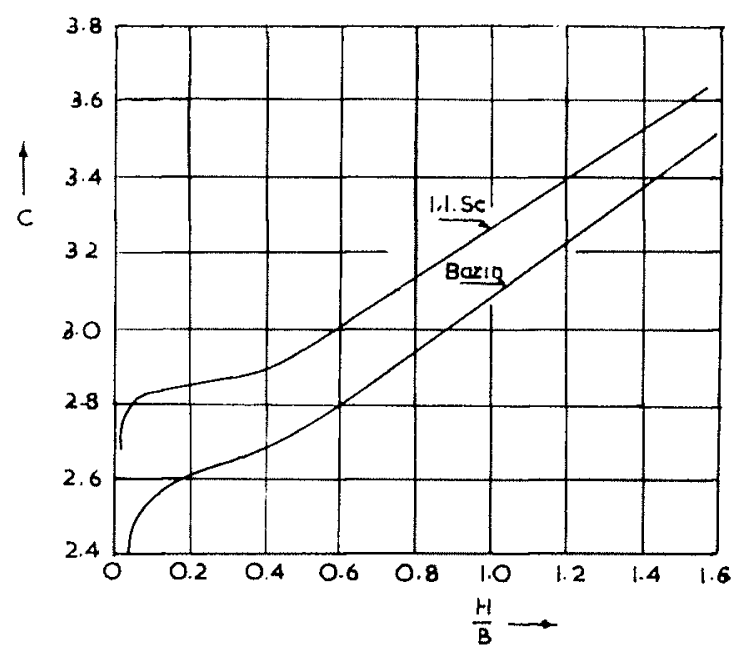

Fic. 10 


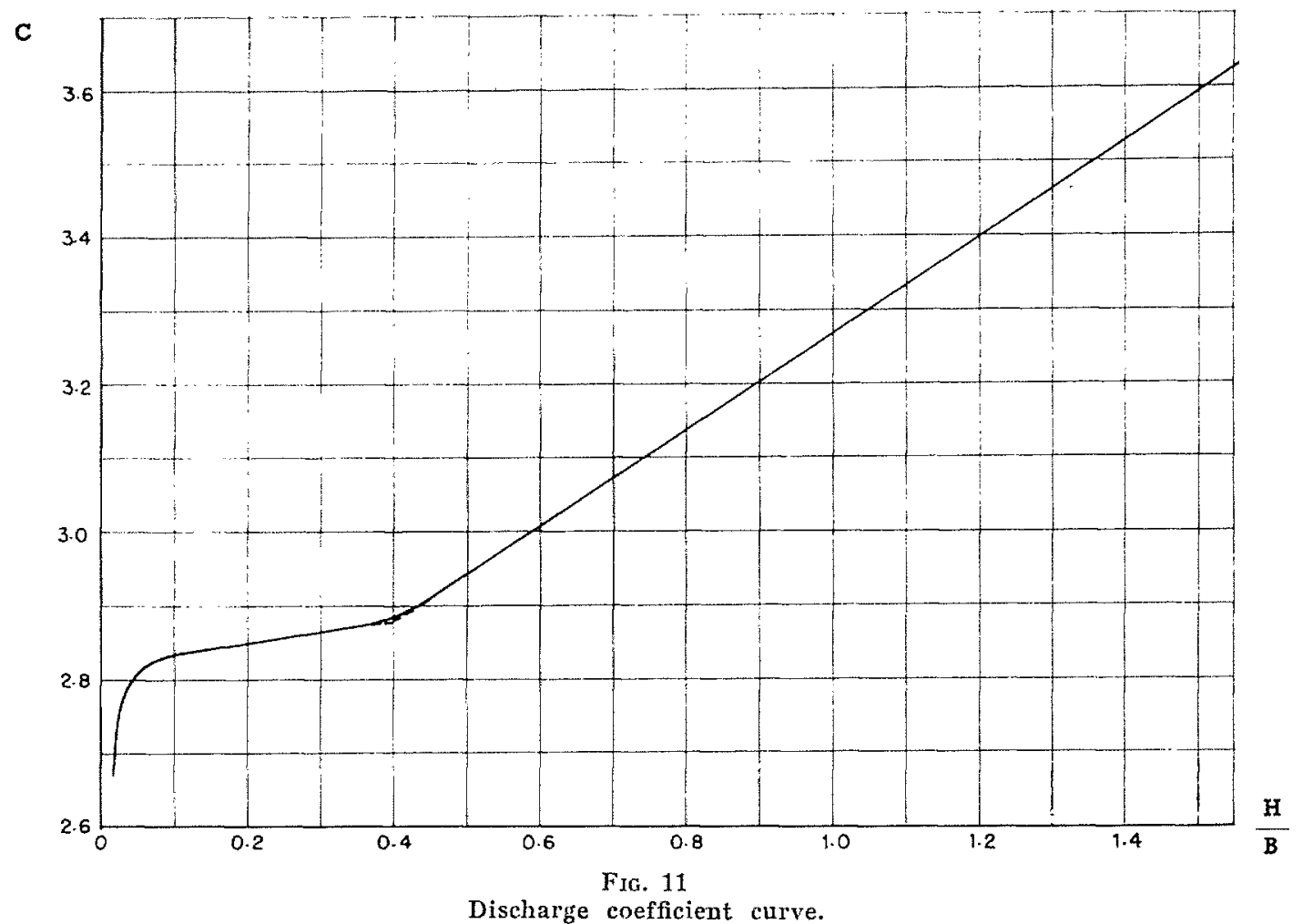

\section{CONCLUSIONS}

1. This paper presents a brief resume of the previous investigations on weirs with finite crest width.

2. Its presents a systematic experimental work on weirs of finite crest width with

$$
0<\mathrm{H} / \mathrm{B} \leqslant 2 \text { and } 0<\mathrm{H} / \mathrm{P}<1 \text {. }
$$

3 . Based on the observations of flow profile and study of the discharge coefficient, weirs of finite crest width have been classified as given below.

REgION 1. - Long-crested weir:

$$
0<\mathrm{H} / \mathrm{B} \leqslant 0.1 \text {. }
$$

The flow pattern consist of series of standing waves. The coefficient of discharge is given by the equation:

$$
\mathrm{C}=3(\mathrm{H} / \mathrm{B})^{0.022}
$$

REgION 2. - Broad-crested weir:

$$
0.1 \leqslant \mathrm{H} / \mathrm{B} \leqslant 0.4
$$

The flow across the weir is parallel to the crest for certain portion. The coefficient of discharge is given by:

$$
\mathrm{C}=0.15(\mathrm{H} / \mathrm{B})+2.82
$$

REgIon 3. - Narrow-crested weir:

$$
0.4 \leqslant \mathrm{H} / \mathrm{B} \leqslant 1.5 \text { to } 1.9 \text {, }
$$

depending on particular $\mathrm{H} / \mathrm{P}$.

The flow pattern is entirely curvilinear. The coefficient of discharge is given by:

$$
\mathrm{C}=0.64(\mathrm{H} / \mathrm{B})+2.63
$$

REgION 4. - Sharp-crested weir:

$$
1.5 \text { to } 1.9 \leqslant \mathrm{H} / \mathrm{B} \text {, }
$$

depending on particular $\mathrm{H} / \mathrm{P}$.

The flow pattern consists of a nappe springing clear off the crest, touching the weir only at the upstream corner. The coefficient of discharge is given by the standard Rehbock formula.

4. The formulae given in equations $6,7,8$ or the curve in Figure 11 can be used to predict the flow over weirs of finite crest width, within the ranges of experimental investigation.

5 . The formulae for coefficient of discharge need the using of units only in feet and seconds and suitable correction factors must be used to give corresponding coefficients in metric units.

\section{Acknowledgements}

The authors are thankful to Sri K. Seetharamiah, Assistant Professor of Civil and Hydraulic Engineering, for his help and encouragement in the work. They also thank Sri N. Rajaratnam, Senior Scientific Officer, for his many suggestions. 


\section{R E F E R E N CE S}

[1] Honton (R, E), - Weir Experiments, Coefficients and Formulas. Water Supply paper 200, Geological Survey, U.S. Department of the Interior, Washington, D.C. (1907). (It contains a summary of classical work of Bazin and many others.)

[2] Fteley (A.) and Stearns (F. P.). - Experiments on flow of water. Transactions of the American Society of Civil Engineers, vol. 12 (1883), pp. 8696.

[3] BaziN (H.). - Expérienoes nouvelles sur l'écoulement en déversoir. Annales des Ponts et Chaussées, vol. 7 , sér. 7 (1896). (Original not referred.)

[4] Rafter (G. W.). - On the flow of water over dams. Transactions of the American Society of Civil Engineers, vol. 44 (1900), pp. 350-359.

[5] JaEger (Charles). - Engineering Fluid Mechanics. Blackie \& Sons, Ltd., London, Glasgow (1956).

[6] Woodburn (J. G.). - Tests of Broad-crested Weirs.
Transactions of the American Society of Civil Engineers, vol. 96 (1932), p. 1797.

[7] Doeringsfeld (H. A.) and Barker (C. L.). - Pressure-Momentum Theory applied to the Broadcrested Weir. Transactions of the American Society of Civil Engineers, vol. 106 (1941), p. 2117.

[8] VEN TE CHow. - Open-channel Hydraulics. McGraw Hill Book Company, Inc., New York, Toronto and Lond on (1959), pp. 52-53.

[9] TracY (H. J.). - Discharge Characteristics of Broad-crested Weirs. Circular 397, Geological Survey, U.S. Dept. of the Interior, Washington, D.C. (1957).

[10] Kindsvater (C. E.). - Draft of Proposed Standards for the use of Weirs and Flumes to measure the flow of water in Open Channels. C. Broad-crested Weirs (unpublished).

[11] Kandaswamy (P. K.) and Rouse (H.), - Characteristies of flow over terminal weirs and sills. Proceedings of the American Society of Civil Engineers, J. Hyd. Division (Aug. 1957), p. 1345.

\title{
Caractéristiques du débit des déversoirs à épaisseur de seuil finie
}

\author{
PAR N.S. GOVINDA RAO E'T D. MURALIDHAR
}

\section{RÉSUMÉ}

Les auteurs présentent d'abord un bref résumé des études antérieures, puis ils établissent, sur la base de nombreuses études expérimentales (voir figure 3' et table 1), une classification des déversoirs en fonction de l'épaisseur de leurs seuils, et donnent les formules permettant de déterminer dans chaque cas le coefficient de débit $C$ (voir la formule 2 et la figure 4 pour les définitions de base).

Nous résumons ci-dessous les résultats obtenus, qui sont valables dans le domaine $0<\mathrm{H} / \mathrm{B} \leqslant 2$ et $0<\mathrm{H} / \mathrm{P}<1$

Les seuils sont classés en quatre catégories :

$1^{\circ}$ Seuii très épais :

$0<\mathrm{H} / \mathrm{B} \leqslant 0,1$

$2^{\circ}$ Seuil épais :

$0,1 \leqslant \mathrm{H} / \mathrm{B} \leqslant 0,4$

3" Seuil étroit :

$0,4 \leqslant H / B \leqslant 1,5$ à 1,9 (suivant la valeur de $\mathrm{H} / \mathrm{P}$ );

$4^{\circ}$ Seuil en mince paroi :

1,5 à $1,9 \leqslant \mathrm{H} / \mathrm{B}$ (suivant la valeur de $\mathrm{H} / \mathrm{P}$ ).

Le coefficient de débit pour les catégories 1 à 3 est donné par les formules (6), (7) et (8) ou par la courbe de la figure 11. (La figure 10 montre la différence avec les résultats de Bazin.) La catégorie 4 est justiciable de la formule de Rehbock.

Note IMPortante : Les unités employées sont les unités anglo-saxonnes. Pour l'utilisation avec les unités métriques $\left(Q\right.$ en $\mathrm{m}^{3} / \mathrm{s}$, $\mathrm{L}$ et $\mathrm{H}$ en $\mathrm{m}$ ), il faut multiplier le coefficient $\mathrm{C}$ donné par les auteurs par 0,55 . 